\title{
Exploring the victimization of British veterans: comparing British beliefs about veterans with beliefs about soldiers.
}

\author{
PHILLIPS, R.H., CONNELLY, V. and BURGESS, M.
}


Exploring the Victimization of British Veterans: Comparing British Beliefs About Veterans With Beliefs About Soldiers
Armed Forces \& Society 2022, Vol. 48(2) 385-409

(C) The Author(s) 2020

(c) (i)

Article reuse guidelines: sagepub.com/journals-permissions DOI: 10.1 177/0095327X20942244 journals.sagepub.com/home/afs

(SAGE

\title{
Rita Helena Phillips' (D, Vincent Connelly ${ }^{2}$, and Mark Burgess ${ }^{2}$
}

\begin{abstract}
Evidence suggests that most of the UK public appreciate currently serving UK Armed Forces personnel but are less positive in their beliefs about veterans. This research examined the social representations held by civilian participants of UK veterans and serving soldiers to understand why veterans may be seen more negatively. An open-ended word association task was completed by 234 UK participants where they were asked to provide three initial responses to the words "veteran" and "soldier" and to evaluate their responses in accordance to prototypicality. The I,404 resultant associations were grouped into I4 thematic clusters. Using the hierarchical evocation method, the results suggest "heroizing associations" to be a defining core element for "soldier" and "veteran" but "victimizing associations" to be an element only for "veteran." Principal component analyses suggest victimizing associations are related to war and deindividuated associations; "heroizing associations" are related to characterizations of the veteran's personality. Implications and future directions are discussed.
\end{abstract}

\footnotetext{
' Robert Gordon University, Aberdeen, United Kingdom

${ }^{2}$ Oxford Brookes University, United Kingdom
}

\section{Corresponding Author:}

Rita Helena Phillips, Robert Gordon University, Garthdee Campus, Aberdeen ABI0 7QB, United Kingdom.

Email: r.phillips5@rgu.ac.uk 


\section{Keywords}

veteran, soldiers, civil-military gap, social representation theory, structural approach

There is an increasing concern that British public perceptions of veterans can be negative (Secretary of State for Defense, 2018). Such concern has led to a call from many politicians and policy makers to include the UK veteran's national reputation in the academic research agenda (i.e., Armour et al., 2018; SSAFA, 2019; YouGov, 2018). However, in contrast to strategies that aim to improve the veteran's national reputation, to date underlying reasons for negative beliefs about veterans remain unclear. Additionally, the question of how public perceptions of veterans may differ from positive public perceptions of serving armed forces personnel remains unaddressed. The present study addresses this by examining word associations that correspond to both soldiers and veterans.

Public perceptions of UK Armed Forces veterans have attracted a considerable amount of literature. Numerous opinion polls and surveys with representative samples of the British population indicate that the public may hold negative beliefs about veterans (i.e., Armour et al., 2018; Ashcroft \& KCMG, 2012, 2017; British Social Attitudes [BSA], 2012; YouGov, 2018). While the public perceive serving armed forces personnel positively, the majority perceive veterans to be more likely to experience unemployment, homelessness, drug addiction, and physical or mental health problems than nonveteran members of the civilian population (i.e., Ashcroft \& KCMG, 2012, 2017; BSA, 2012; ICM, 2011-2015). Although these beliefs may be somewhat accurate for veterans in an international context (Hoerster et al., 2012; Thompson et al., 2014), they are disputed for UK veterans, and research illustrates very much lower actual difficulties for veterans than the public perceives (Connelly \& Burgess, 2013; King's Centre for Military Health Research, 2014; MOD Career Transition Report, 2014; MOD Statistic Notice, 2015). However, it is also the case that studies which report the British public may also hold many favorable views of those who have served in the UK Armed Forces. For example, the majority of UK respondents from representative opinion polls and surveys characterized veterans as highly skilled, capable, and valorous individuals (Ashcroft \& KCMG, 2012, 2017; BSA, 2012; ICM, 2011-2015; YouGov, 2018). This would suggest that the British public believes those who have served in the UK Armed Forces are both heroic and victims.

Little scientific attention has been devoted to why members of the British public may hold potentially contradictory, heroizing, and victimizing sentiments about veterans. In addition, it remains unclear why negative perceptions of veterans are so pervasive and persistent over time, given that they are not consistent with the reality of most veterans' lives (cf. Ashcroft, 2014; Ashcroft \& KCMG, 2012, 2017; BSA, 2012; ICM, 2011-2015). This article addresses this gap in knowledge by utilizing word-associations informed by the structural approach in social 
representation theory (Abric, 1987; Flamnet, 1994) to examine the freely recalled associations with "veteran" and the freely recalled associations with "soldier." In doing so, we explore similarities and differences between individual representations of active service personnel and veterans and develop working hypotheses from an operational perspective that future research may want to take into consideration.

\section{Victimization and Heroization of Veterans}

Why do individuals in British society hold both victimizing and heroizing perceptions of veterans? Research on rhetorical functions show that strong associations between heroism and military service may represent a deeply rooted British cultural assumption (i.e., Coy et al., 2008; Gibson, 2012; Gibson \& Condor, 2009). This cultural assumption facilitates conceptualizions of military service as a solemn function and is perpetuated by descriptions of existential matters (i.e., "evil transgressors" vs. "righteous us") and symbolic values (i.e., "freedom" vs. "oppression") in relation to "serving the country" (Gibson, 2012). This allows one group of people to be categorized differently to another and treated with more respect than their comparison group. This is exemplified by subgroups in society that claim recognition on behalf of veterans who were part of the same subgroup (cf. Gibson, 2012). For example, a speech given by the head of the National Association for Gypsy Women in which a moral right to recognition and respect for their group was claimed on behalf of Gypsy men fighting in WW2 (Gibson, 2012). Appreciative attitudes toward veterans that were outlined in polls and surveys (i.e., Ashcroft \& KCMG, 2012, 2017; BSA, 2012; ICM, 2011-2015) may therefore be based on prevailing, social notions that relate veterans arbitrarily to heroic sentiments.

Actions in service that associate veterans with heroism may also lead the public to attribute service-related injuries to victimhood. For example, the public has been increasingly led to view mental and physical injury as unavoidable consequences of war exposure, with public sympathy increasing over time as a consequence (Jones \& Wessely, 2005; McCartney, 2011). This is particularly the case if the public perceives warfare as illegitimate. Then, veterans are culturally conceptualized in the context of suffering from post-traumatic stress disorder and trauma (McGarry, 2012). Cultural representations of veterans in media, literature, and films draw almost exclusively on the veteran's horrific experiences on the battlefield and the negative consequences this has on the veteran's mental and physical health (i.e., Chattarji, 2000; De Groot, 1995; Goldensohn, 2006). Socially constructed images of veterans then overlap with definitions of victims in a victimological context (McGarry, 2012). Once established, this socially constructed narrative of victimhood is difficult to shift (Connelly \& Burgess, 2013).

Culturally anticipated mental and physical health problems may have negative consequences for the veteran population. It is known that mentally and physically ill individuals are publicly discriminated against and perceived to have diminished competence (cf. Hipes et al., 2015; Link et al., 1999). Therefore, the negative stigma 
that is related to health issues and the military (Ben-Zeev et al., 2012; GreeneShortridge et al., 2007) may be harmful for the veteran population and have important practical implications. For example, publicly pertinent negative and erroneous perceptions of veterans may deter recruitment and cause disaffection among those who are currently serving as well as influence how veterans transition back into civilian society (cf. Forster, 2006; Hines et al., 2015). Beliefs that relate veterans to homelessness, drug addiction, and physical or mental health problems may impede employment and hinder a successful reintegration of veterans into the civil society, even if those beliefs are held implicitly.

Despite previous research indicating that victimizing beliefs may be harmful, little empirical evidence explores why members of the British public may hold these beliefs and how negative beliefs about veterans may be combined with positive, heroizing beliefs. However, social representation theory may offer an explanatory framework to understand this seemingly contradictory position.

\section{Theoretical Framework}

To understand public perceptions of veterans, complex interactional processes at societal and individual levels need to be considered. These involve cultural structures that account for interindividual distribution of information and intraindividual processing that evaluates, accepts, or rejects culturally prevalent information (cf. Jovchelovitch, 2001; Sellars et al., 1997). As a content and process, social representations constitute a particular modality of knowledge that takes interactional processes into account (Moscovici, 1988, 2000, 2001). Social representations are "a form of knowledge, socially produced with a practical function, namely to contribute to the construction of a reality shared by a social group or entity" (Jodelet, 1991, p. 36). To that end, they are culturally shared sets of understandings of socially significant realities and, in this context, such social representations have four essential functions: (1) a function of knowledge (understanding and explaining reality), (2) a function of identity (defining and maintaining individual and group identity), (3) a function of guidance (guiding behaviors and practices), and (4) a function of justification (justifying behaviors and standpoints posteriori; cf. Abric, 1989). Therefore, social representations capture how people make their world meaningful by observing communication processes that determine the content and structure of beliefs and practices (Moscovici, 1984). As a constitutive paradigm of social psychology (i.e., Abric, 1996; Jovchelovitch, 2001) many qualitative and quantitative methodological perspectives have been used to examine social representations (i.e., Abric, 1989; Jovchelovitch, 2001; Lo Monaco et al., 2016).

The present project focusses on the structural approach in social representation theory (Abric, 1987) that defines social representations as a "hierarchical, coherent system" of structured and organized sets of meaning, beliefs, and attitudes. Social representations are thought to be composed of two interacting and qualitatively different subsystems, the central system and the peripheral system. The central system has a 
stabilizing function and is therefore composed of a small number of unambiguous and consensual elements. These central elements are unconditional, essential, constitutive properties that give meaning to the entire representation. In contrast, the peripheral system constitutes an interface between the representation of reality and reality itself. The peripheral system is composed of contextually and situationally dependent components that are "conditional" in nature (peripheral elements; cf. Flamnet, 1994).

From this perspective, the social representation of "veteran" may comprise hierarchically structured elements. More important elements, central elements, would be unconditional descriptors that describe the basic constituents of beliefs about veterans. Without these basic constituents, a person could not be categorized a veteran. Having served in the UK Armed Forces would be a basic constituent to being categorized as a veteran. In contrast, less important, situationally dependent descriptors would represent peripheral elements. For example, injury may be an adequate descriptor in some instances (i.e., injured individuals at a parade to honor those who experience service-related injuries) but not in other circumstances (i.e., injured individuals in a hospital — not all injured individuals are veterans).

Contradictory heroizing and victimizing perceptions of veterans may therefore be explained by differences in the centrality of elements. For example, veterans may generally be heroized only in specific instances related to victimizing sentiments. While heroizing sentiments would therefore constitute a central element, victimizing sentiments would be a less important, situationally dependent peripheral element (or in similar vice versa constellations). However, if victimizing and heroizing sentiments would be of equal importance, then these sentiments may be held in locally but not globally consistent rationalities. Different beliefs would, therefore, possess different kinds of justifications which respond to the theoretical notion of cognitive polyphasia (Moscovici, 2000), which will now be explained.

Cognitive polyphasia, first coined by Moscovici (1984), describes incompatible representations that refer to the same reality but organize and interpret this reality in distinct ways. In contrast to "cognitive dissonance" (Festinger, 1957) that supposes an individual's inability to hold dichotomous representations without negatively affecting the self's equilibrium, cognitive polyphasia assumes that as long as each belief is locally consistent, contradictory beliefs can coexist within the same representations side by side. Therefore, "it is in the context of different life worlds that holding on to "contradictory" representations makes sense" (Wagner et al., 2000, p. 306). Specifically, different circumstances and social contexts require situationally dependent responses in order to behave in functional ways (Provencher, 2011).

\section{Aims of the Study}

The aim of this study is to investigate perceptions of veterans compared to serving armed forces personnel and to explore why negative and erroneous beliefs of veterans may be held by the British public. Taking the structural approach in social representation theory, a quantitative free word association task was utilized to 
determine the centrality of beliefs about veterans and to compare these beliefs with perceptions of serving armed forces personnel. In addition, an assessment of the relationship within the given word-associations was undertaken to examine patterns of contextual differences in the perceptions of veterans and serving armed forces personnel. The key research questions are as follows:

1. What are the central and peripheral elements of the public perceptions of veterans? How do the central and peripheral elements of perceptions of veterans compare with the central and peripheral elements of the public perceptions of serving armed forces personnel?

2. Are beliefs about veterans contextually and situationally dependent or are they globally consistent? How do perceptions of veterans compare with perceptions of serving armed forces personnel?

\section{Method}

\section{Participants}

After receiving ethical approval from Oxford Brookes University (UREC Registration Nr. 171072), a convenience sample of 234 participants who lived in the UK was recruited between September 2017 and January 2018. The sociodemographic characteristics of the recruited population are indicated in Table 1.

\section{Materials and Procedure}

Three successive steps were carried out to examine the representational content:

(1) Participants were asked to produce the first three words that came to their mind when seeing the stimuli terms "soldier" and "veteran" on a computer screen. Participants were randomly presented with either stimuli first, and to ensure they answered rapidly, a timer was displayed on the screen underneath the text entry form fields where they were required to type their three associated words (free association task; cf. di Giacomo, 1980; LorenziCioldi, 1988; Sarrica \& Contarello, 2010; cf. Clemence et al., 2014); (2) After the three word associations for "veteran" and "soldier" were provided, the participants were asked to rank the prototypicality of each of their three word associations for both "soldier" and "veteran" on a 5-point Likert-type scale (extremely important, very important, moderately important, slightly important, not at all important). This process was not timed, and participants were encouraged to be reflective in their rankings (cf. Abric, 2003; Dany et al., 2015; Lo Monaco et al., 2016); (3) Finally, participants were asked to provide sociodemographic information about themselves.

The word "soldier" was chosen to represent serving armed forces personnel. Polling in the UK indicates that the army is the most recognized of the branches 
Table I. General Demographic Information.

\begin{tabular}{ll}
\hline Demographic Characteristic & Frequency \\
\hline Gender & Female: I5I (64.5\%) \\
& Male: $83(35.5 \%)$ \\
Age & Nonbinary: $0(0 \%)$ \\
Education & Above A-levels: I28 (54.7\%) \\
& A-levels or equiv.: I05 (44.9\%) \\
Nationality & Below A-levels: I (0.4\%) \\
Ethnicity & British: I93 (82.5\%) \\
& Other: 4 I (I7.5\%) \\
& White: I $93(82.5 \%)$ \\
& Asian/Asian British: 21 (9\%) \\
& Black/African/Caribbean: $5(2.1 \%)$ \\
Religion & Mixed/multiple ethnic: $9(3.8 \%)$ \\
& Other: $6(2.3 \%$ \\
& No religion: II0 (47\%) \\
& Christian: 102 (43.6\%) \\
& Muslim: $6(2.6 \%)$ \\
\hline
\end{tabular}

of the armed forces and "soldier" is the generic term for a serving member of the army (BMG Research, 2017). While there have been debates in the UK about the word "veteran" (Burdett et al., 2013), it is the most popular reference for ex members of the armed forces in the media in the UK (Phillips et al., in press).

\section{Data Analyses}

Content analysis (CA). A theme-based CA (Bardin, 1977) was conducted to facilitate further descriptive and parametric analyses. A process of grouping together semantically similar answers assisted with data aggregation and made the corpus of data more uniform and less ambiguous (i.e., Bolasco et al., 1999; Sarrica \& Contarello, 2010). Semantically similar answers such as items which expressed the same semantic content and differed in grammatical form, expression, spelling, or upper or lower cases were put together (i.e., Honor-honour, Bravery-brave). The evaluation of saliences, frequencies, and characteristics of associations, informed by relevant literature (i.e., Joffe \& Staerkle, 2007; McCulloch, 1995; Sarrica \& Contarello, 2010), guided the subsequent construction of the theme-based categories.

\section{Hierarchical Evocation Method (HEM)}

The HEM was utilized to distinguish between central and peripheral elements (Dany et al., 2015; Lo Monaco et al., 2017) and is commonly used in social representational research (i.e., Abric, 2003; Baquiano \& Mendez, 2016; Dany et al., 2015; Gomes 


\begin{tabular}{|l|l|l|}
\hline & $\begin{array}{c}\text { High Average Order of } \\
\text { Evocation (A.O.E) }\end{array}$ & $\begin{array}{c}\text { Low Average Order of } \\
\text { Evocation (A.O.E) }\end{array}$ \\
\hline High Frequency & Zone of Central Core & First Periphery \\
\hline Low Frequency & Contrasting Zone & Second Periphery \\
\hline
\end{tabular}

Figure I. Hierarchical evocation method model.

et al., 2008; Lo Monaco et al., 2017; Roland-Lévy et al., 2010). It satisfies two criteria: First, the frequency of element occurrence and second, the hierarchical order of valence (importance). Cross-referencing frequency and importance produces a fourarea chart (see Figure 1). The threshold for frequencies is determined by the number of associations divided by the number of previously defined elements (thematic clusters). The distinction between "high" and "low" importance of these elements is made by utilizing the valence/importance ratings' mean as the cutoff point.

The left upper corner of the chart contains the representation's central elements based on high frequencies and importance. These central elements ought to be defined by the homogeneity of group understandings, stability, coherence, change resistance, and rigidity. The bottom left cell comprises categories which are named by fewer people but are still considered as very important. This zone, the contrasting zone, represents elements that may be important to subgroups in the recruited population. The first and second periphery contain mutant elements, oscillating in the adaptation to the situation and social context (cf. Baquiano \& Mendez, 2016). While the first periphery contains frequent but unimportant elements, the second periphery is constituted of infrequent and unimportant elements. The first and second peripheries allow for the integration of individual experiences and tolerate heterogeneity and contradictions.

Principal component factor analysis (PCA). To observe how elements (that are the previously coded thematic clusters) relate to each other, a PCA was utilized. PCA simplifies patterns of relationships underlying the measured variables (Beavers et al., 2013) by reducing the number of variables while retaining as much of the original variance as possible (Conway \& Huffcutt, 2003). In doing so, links and patterns between profiles of individual responses in element valence can be observed. The examination of covariation, oppositions, and independence of element valence scorings allows a review and exploration of response patterns. Comparisons between the response patterns of "soldier" and "veteran" may allow important valence differences between them to become apparent (cf. Hines et al., 2015).

\section{Results}

Participants generated a total of 1,404 word associations. These were downloaded from the online survey tool Qualtrics and transposed to SPSS along with 


\begin{tabular}{|c|c|c|c|c|}
\hline & Data Utilized & $\begin{array}{l}\text { Method of } \\
\text { Analysis }\end{array}$ & $\begin{array}{c}\text { Description of Steps } \\
\text { of Analysis }\end{array}$ & $\begin{array}{c}\text { Research Question } \\
\text { to Answer }\end{array}$ \\
\hline Step I & $\begin{array}{l}\text { Raw Word } \\
\text { Associations }\end{array}$ & $\begin{array}{l}\text { Content } \\
\text { Analysis }\end{array}$ & $\begin{array}{l}\text { Utilizing previous } \\
\text { research and literature } \\
\text { to create distinct } \\
\text { thematic clusters }\end{array}$ & Preparatory step \\
\hline Step 2 & $\begin{array}{c}\text { Thematic } \\
\text { clusters from } \\
\text { Content } \\
\text { Analysis, } \\
\text { Importance } \\
\text { Ratings }\end{array}$ & $\begin{array}{l}\text { Hierarchical } \\
\text { Evocation } \\
\text { Model }\end{array}$ & $\begin{array}{l}\text { Utilizing the frequency } \\
\text { of thematic cluster } \\
\text { evocation and the } \\
\text { importance of thematic } \\
\text { cluster evocation to } \\
\text { differentiate between } \\
\text { central thematic } \\
\text { clusters (elements) and } \\
\text { peripheral thematic } \\
\text { clusters (elements) }\end{array}$ & $\begin{array}{l}\text { What are central and } \\
\text { peripheral elements in } \\
\text { perceptions of } \\
\text { veterans? How do } \\
\text { central and peripheral } \\
\text { elements in } \\
\text { perceptions of veterans } \\
\text { compare with central } \\
\text { and peripheral } \\
\text { elements in } \\
\text { perceptions of } \\
\text { soldiers? }\end{array}$ \\
\hline Step 3 & $\begin{array}{l}\text { Importance of } \\
\text { thematic } \\
\text { cluster } \\
\text { evocation }\end{array}$ & $\begin{array}{l}\text { Principal } \\
\text { Component } \\
\text { Factor } \\
\text { Analysis }\end{array}$ & $\begin{array}{c}\text { Utilizing the } \\
\text { importance of thematic } \\
\text { cluster (element) } \\
\text { evocation to describe } \\
\text { systematic } \\
\text { interdependencies } \\
\text { between thematic } \\
\text { clusters (elements) and } \\
\text { so to detect latent } \\
\text { answering patterns }\end{array}$ & $\begin{array}{l}\text { Do answering patterns } \\
\text { of veterans suggest that } \\
\text { beliefs about veterans } \\
\text { are contextually and } \\
\text { situationally dependent } \\
\text { or globally consistent? } \\
\text { How answering } \\
\text { patterns in perceptions } \\
\text { of veterans compare } \\
\text { with answering } \\
\text { patterns in perceptions } \\
\text { of soldiers? }\end{array}$ \\
\hline
\end{tabular}

Figure 2. Overview of the data analysis procedure.

participants' importance rankings and the sociodemographic information about the participants. The word associations were then grouped into thematically coherent clusters (CA). These clusters were utilized for the subsequent hierarchical evocation models and the PCA to differentiate between central and peripheral clusters and to detect response patterns. An overview of the procedure of analysis can be found in Figure 2.

\section{CA}

An inductively driven coding chart was generated. Findings from previous literature were used to amend the original coding chart into the final 14 thematic cluster chart (i.e., Joffe \& Staerkle, 2007; McCulloch, 1995; Sarrica \& Contarello, 2010; cf. Table 2). Inter-rater reliability was validated by concordance in category ratings 
Table 2. Overview of Thematic Clusters With Definition and Examples.

Thematic Clusters Definition and Examples

I. Heroizing associations

\section{Associations with experience and maturity}

3. War

4. Positive character traits

5. In-group belonging

6. Victimizing associations

7. Negative character traits
Positive descriptors of how public should feel(e.g., thank you, grateful, deserving of respect, respectable, honored);

Descriptions of looking up to something/somebody (e.g., admirable, heroic, brave, impressive, amazing);

References to positive protective role

(e.g., savior, protector, guardian, people who have protected us, protective)

Associations referring to increased experience and age

(e.g., experienced, old, old age, finished service, discharged)

Associations referring to war

(e.g., unsafe, destruction, guns, bombs, improvised explosive device, rifle)

Associations of positive character traits that are aligned with Western values

(e.g., trustworthy, smart, intelligent, reliable, forwardthinking)

Associations related to personality and contributing to employability

(e.g., committed, dedicated, confident, disciplined, resilient)

Associations referring to British or in-group belonging; associations grounded on national inclusion or group belonging

(e.g., one of us, ours, comradeship, together, bond)

Associations referring to suffering from

- Physical disabilities

(e.g., injuries, wounded, maimed, loss of limbs, wheelchair)

- Mental health problems

(e.g., post-traumatic stress disorder, mad, suicide, mental problems, mental, shell shock)

- Social negligence and financial problems (e.g., homelessness, unemployed, forgotten, abandoned, neglected)

- Unfaithful superiors/government

(e.g., misguided, betrayed, mistreated, pawn, lies)

Associations with being negative character traits that cannot be aligned with Western values

(e.g., harsh, selfish, dumb, racist, uneducated)

Associations which are related to personality and impact employability negatively

(e.g., grumpy, obedient, conforming, lazy, unskilled) 
Table 2. (continued)

\begin{tabular}{|c|c|}
\hline Thematic Clusters & Definition and Examples \\
\hline 8. Job/occupation & $\begin{array}{l}\text { Associations referring to jobs, being employed and } \\
\text { descriptive synonyms of these aspects } \\
\text { (e.g., job, employee, occupation, Ministry of Defence } \\
\text { (MOD) jobs, career) }\end{array}$ \\
\hline $\begin{array}{l}\text { 9. Reference to UK and } \\
\text { international politics/ } \\
\text { politicians }\end{array}$ & $\begin{array}{l}\text { Naming UK and international politicians and political } \\
\text { motives for the deployments in Iraq and Afghanistan } \\
\text { (e.g., Blair, Bush, Saddam, Obama, Nigel Farage) }\end{array}$ \\
\hline $\begin{array}{l}\text { 10. Reference to place of } \\
\text { deployment }\end{array}$ & $\begin{array}{l}\text { Describing or naming cities and countries to which the UK } \\
\text { Forces have been deployed; } \\
\text { (e.g., Afghanistan, Iraq, Helmand, desert, hot) } \\
\text { Synonyms for deployment or for being deployed } \\
\text { (e.g., tours, mission, deployment, not here, far away) }\end{array}$ \\
\hline II. Physical description & $\begin{array}{l}\text { Physical description of the person without references to } \\
\text { personality } \\
\text { (e.g., man, individual, person, beard, woman) }\end{array}$ \\
\hline 12. Military specialism/trade/role & $\begin{array}{l}\text { Reference to a group within the Forces and to } \\
\text { membership within this group } \\
\text { (e.g., Royal Air Force, soldier, army, navy, armed forces) }\end{array}$ \\
\hline I3. Peace & $\begin{array}{l}\text { Associations which previous research found to be related } \\
\text { to peace } \\
\text { (e.g., peace, freedom, free, peaceful, peace one day) }\end{array}$ \\
\hline 14. Other & $\begin{array}{l}\text { Answers based on random associations which did not fit } \\
\text { any of the } 13 \text { thematic clusters } \\
\text { (e.g., don't know, ..,?, -, x, ., tofu, green) }\end{array}$ \\
\hline
\end{tabular}

with two research assistants (87.65\% and $83.85 \%$ inter-rater concordance). An overview of the thematic clusters can be found in Table 2 .

\section{HEM}

HEM models were created for the stimuli words "veteran" and "soldier." The mean frequency $(f)$ threshold was created by dividing the number of words included in the analysis (702 associations) by the number of categories (14), resulting in a value of 50 for both stimuli words. The mean value for the importance ratings (average order of evocation) was 1.18 for the stimulus term "veteran" and 1.22 for "soldier." The associations that were grouped into thematic clusters through the categorization in the CA were handled as elements and allocated to the central, contrasting, and peripheral zones of the HEM models (cf. Figures 3 and 4).

The results suggest that both stimuli words were well-defined representations with organized central cores. The two stimuli words are structured around stable, highly salient, and evocative cores. Out of 14 thematic clusters, only 7 clusters were part of the central core or the contrasting zone in both HEM models. The other seven thematic clusters were part of the second periphery, indicating very little importance. 


\begin{tabular}{|c|c|c|}
\hline & High Importance (>I.I8) & Low Importance $(<1.18)$ \\
\hline & Zone of Central Core & First Periphery \\
\hline \multirow[t]{2}{*}{$\begin{array}{l}\text { High } \\
\text { Frequency } \\
(>50)\end{array}$} & $\begin{array}{l}\text { Heroizing Associations } \\
\left(f^{\prime}=147, A . O . E^{2}=1.84\right) \\
\text { Victimizing Associations } \\
\left(f^{\prime}=100, \text { A.O. } E^{2}=1.7 I\right) \\
W a r \\
\left(f^{\prime}=80, \text { A.O. } E^{2}=2.33\right) \\
\text { Associations to Experience } \\
\text { and Maturity } \\
\left(f^{\prime}=162, \text { A.O. } E^{2}=1.97\right) \\
\text { Human Resources of the Military } \\
\left(f^{\prime}=88, \text { A.O.E } E^{2}=1.57\right)\end{array}$ & $\mathbf{x}$ \\
\hline & Contrasting Zone & 2nd Periphery \\
\hline $\begin{array}{l}\text { Low } \\
\text { Frequency } \\
(<50)\end{array}$ & $\begin{array}{l}\text { Positive Characterisation } \\
\text { of the Personality } \\
\left(f^{\prime}=48, \text { A.O. } E^{2}=1.23\right) \\
\text { Other } \\
\left(f^{\prime}=18, \text { A.O. } E^{2}=1.35\right)\end{array}$ & $\begin{array}{l}\text { Negative Characterisation } \\
\text { of the Personality } \\
\left(f^{\prime}=3, \text { A.O.E } E^{2}=.75\right) \\
\text { UK Groupiness } \\
\left(f^{\prime}=16, \text { A.O.E } E^{2}=.75\right) \\
\text { Reference to UK and } \\
\text { International Politics/Politicians } \\
\left(f^{\prime}=12, \text { A.O.E }{ }^{2}=.73\right) \\
\text { Reference to Place of Deployment } \\
\left(f^{\prime}=2, \text { A.O.E } E^{2}=.46\right) \\
\text { Physical Description } \\
\left(f^{\prime}=11, \text { A.O.E } E^{2}=.77\right) \\
\text { Job/Occupation } \\
\left(f^{\prime}=13, \text { A.O. } E^{2}=.94\right) \\
\text { Peace } \\
\left(f^{\prime}=2, \text { A.O.E } E^{2}=.08\right)\end{array}$ \\
\hline $\begin{array}{l}f=\text { Frequen } \\
{ }^{2} \text { A.O.E }=\text { Av } \\
\text { evocatiom }\end{array}$ & se Order of Evocation (describin & mean imporatnce of thematic cluster \\
\hline
\end{tabular}

Figure 3. Hierarchical evocation method model: Veteran.

The central elements for "veteran" were "war," "victimizing associations," "heroizing associations," "associations with experience and maturity," and "human resources of the military." The central elements cover a wide range of descriptive elements. The absence of words in the first periphery indicate that "veteran" may be 


\begin{tabular}{|c|c|c|}
\hline & High Importance (>I.22) & Low Importance $(<1.22)$ \\
\hline & Zone of Central Core & First Periphery \\
\hline \multirow[t]{2}{*}{$\begin{array}{l}\text { High } \\
\text { Frequency } \\
(>50)\end{array}$} & $\begin{array}{l}\text { Heroizing Associations } \\
\left(f^{\prime}=143, \text { A.O. } E^{2}=I .57\right) \\
\text { War } \\
\left(f^{\prime}=22 I, A . O . E^{2}=2.22\right) \\
\text { Positive Characterisation of the } \\
\quad \text { Personality } \\
\left(f^{\prime}=70, \text { A.O. } E^{2}=1.27\right) \\
\text { Human Resources of the Military } \\
\left(f^{\prime}=60, \text { A.O. } E^{2}=1.42\right)\end{array}$ & $\mathbf{x}$ \\
\hline & Contrasting Zone & 2nd Periphery \\
\hline $\begin{array}{l}\text { Low } \\
\text { Frequency } \\
(<50)\end{array}$ & $\begin{array}{l}\text { Victimizing Associations } \\
\left(f^{\prime}=34, A \cdot O \cdot E^{2}=1.94\right) \\
\text { Associations to Experience and } \\
\text { Maturity } \\
\left(f^{\prime}=25, \text { A.O. } E^{2}=2.45\right) \\
\text { Other } \\
\left(f^{\prime}=27, \text { A.O. } E^{2}=I .5 I\right)\end{array}$ & $\begin{array}{l}\text { Negative Characterisation of the } \\
\text { Personality } \\
\left(f^{\prime}=25 \text { A.O.E } E^{2}=.85\right) \\
\text { UK Groupiness } \\
\left(f^{\prime}=24, \text { A.O. } E^{2}=.75\right) \\
\text { Reference to UK and } \\
\text { International Politics/Politicians } \\
\left(f^{\prime}=8, \text { A.O. } E^{2}=.8 I\right) \\
\text { Reference to Place of Deployment } \\
\left(f^{\prime}=7, \text { A.O.E }{ }^{2}=.57\right) \\
\text { Physical Description } \\
\left(f^{\prime}=45, \text { A.O.E } E^{2}=.78\right) \\
\text { Job/ Occupation } \\
\left(f^{\prime}=10, \text { A.O. } E^{2}=.98\right) \\
\text { Peace } \\
\left(f^{\prime}=3, \text { A.O.E } E^{2}=.07\right)\end{array}$ \\
\hline \multicolumn{3}{|c|}{$\begin{array}{l}{ }^{\prime} f=\text { Frequency } \\
{ }^{2} \text { A.O.E }=\text { Average Order of Evocation (describing mean imporatnce of thematic cluster } \\
\text { evocatiom) }\end{array}$} \\
\hline
\end{tabular}

Figure 4. Hierarchical evocation method model: Soldier.

a well-defined and culturally hegemonic representation with a set of uniform and widely shared understandings. The central elements for "soldier" were "war," "heroizing associations," "positive characterization of the personality," and "human resources of the military." Comparisons between the stimuli terms "soldier" and "veteran" show that, aligned with previous research (cf. BSA, 2012; Hines et al., 2015), veterans are less positively characterized than soldiers. Besides "heroizing 
associations," the stimulus term "soldier" also includes the element "positive characterization of the personality" as part of its central core.

Two notable differences concern the elements "associations with maturity and experience" and "victimizing associations." The results suggest that the respondents associate increased experience and age with veterans as well as associations that are related to suffering more frequently when thinking about veterans. In addition, as the veteran's central core accommodated the elements "victimizing associations" and "heroizing associations," these elements may be embedded within different contexts following the theoretical notion of cognitive polyphasia. This would suggest that homogeneity and uniformity in the central core would be maintained by understanding contradictory elements such as victimizing and heroizing associations as belonging to different patterns of thought. This will be examined further by conducting a PCA.

\section{PCA}

Test measures of sampling adequacy were examined by observing Kaiser-MeyerOlkin (KMO) measure and Bartlett's test of sphericity. All necessary requirements were met (KMO [Bartlett's test of sphericity]: veteran $=.70, \chi^{2}(91)=327.17 p<$ .001 , soldier $\left.=64, \chi^{2}(91)=270.26, p<.001\right)$. The principal component factor analyses with varimax rotation indicated a two-factor matrix to be the most appropriate solution for both stimuli words. The choice of structure models was clear-cut as all three, four, and five model solutions did not fulfill the criteria of accommodating at least three item loadings above the cutoff point of .4 per component (Costello \& Osborne, 2005; Raubenheimer, 2004). Moreover, examinations of scree plot curves provided further evidence for the two factor models.

The factor models suggest high similarities between "veteran" and "soldier" (Tables 3 and 4). In both factor models, Component 1 accommodates the elements "associations with experience and maturity," "war," "human resources of the military," "victimizing associations," "physical description," and "reference to UK and international politics/politicians." Component 1 may therefore indicate that the recollection of victimization might be starkly interwoven with focusing on the unique challenges of deployment implied in the military contract and a superficial description of the individual in the context of these challenges. Therefore, victimizing associations may be embedded in a deindividuated perspective and thus in a less person-centered approach in characterizing those who serve or have served in the UK Armed Forces. In contrast, Component 2 accommodates "positive characterization of the personality," "heroizing associations," and "negative characterizations of the personality" (for the veteran factor model) that stood in an oppositional relationship with "job/occupation." Therefore, Component 2 may suggest that the heroization of those who serve or who have served may relate to anticipations of personality traits. 
Table 3. Rotated Component Matrix for "Veteran."

\begin{tabular}{lrr}
\hline & \multicolumn{2}{c}{ Component } \\
\cline { 2 - 3 } Elements & \multicolumn{1}{c}{2} \\
\hline Associations to experience and maturity & .67 & .17 \\
War & .62 & -33 \\
Human resources of the military & .60 & .12 \\
Victimizing associations & .59 & .20 \\
Physical description & .58 & -.29 \\
Reference to UK and international politics/politicians & .47 & .18 \\
Other & .47 & .71 \\
Reference to place of deployment & .38 & .45 \\
Peace & -.21 & .43 \\
Positive characterization of the personality & & -.41 \\
Negative characterization of the personality & & .29 \\
Heroizing associations & & .22 \\
Job/occupation & & \\
UK groupiness & & \\
\hline
\end{tabular}

Note. Extraction method: Principal component analysis. Rotation method: Varimax with Kaiser normalization. ${ }^{\mathrm{a}}$

${ }^{a}$ Rotation converged in three iterations.

Table 4. Rotated Component Matrix for "Soldier."

\begin{tabular}{lrr} 
& & Component \\
\cline { 2 - 3 } Elements & \multicolumn{2}{c}{2} \\
\hline War & .65 & .21 \\
Associations to experience and maturity & .59 & \\
Physical description & .53 & .51 \\
Human resources of the military & .51 & .29 \\
Other & .34 & -.21 \\
Victimizing associations & .23 & -.21 \\
Reference to places of deployment & & .61 \\
Job/occupation & .51 \\
Positive characterization of the personality & .46 & -.51 \\
Heroizing associations & .32 \\
Reference to UK and international politics/politicians & .10 & -.31 \\
Negative characterization of the personality & -.17 & .23 \\
Peace & -.19 & \\
UK groupiness & & \\
\hline
\end{tabular}

Note. Extraction method: Principal component analysis. Rotation method: Varimax with Kaiser normalization. ${ }^{\mathrm{a}}$

${ }^{a}$ Rotation converged in three iterations. 
The PCA therefore suggests that consistency in the central core of "soldier" and "veteran" may be explained by cognitive polyphasia (Moscovici, 1988), meaning that victimizing and heroizing associations are embedded within different contexts. The present results may indicate that the saliency of contextual information may impact on characterizations of veterans.

\section{Discussion}

The present exploratory study examined how beliefs about veterans are structured and how these beliefs compare with beliefs about personnel currently serving in the UK Armed Forces represented as a "soldier" (cf. Hines et al., 2015). A series of analyses that investigated the structure of "veteran" and "soldier" from a social representational perspective produced explorative key findings, providing an insight into the original two research questions.

1. What are the central and peripheral elements of the public perceptions of veterans? How do the central and peripheral elements of perceptions of veterans compare with the central and peripheral elements of the public perceptions of soldiers?

The hierarchical evocation method models suggests that "heroizing associations" are core elements in individual perceptions of both "veteran" and "soldier." In contrast, "associations with experience and maturity" and "victimizing associations" are only part of the central core in perceptions of "veteran" but not of "soldier." Additionally, the element "positive characterization of the personality" is part only of the central core in individual perceptions of "soldier" but not of "veteran." The results indicate that the representations of "veteran" and "soldier" are similarly structured but that "soldier" is more favorably viewed than "veteran." In contrast to "soldier," the results suggest that "veteran" is associated with an older population that experiences health problems.

These results reflect recent polling data in the UK where roughly equal numbers of participants consider service in the armed forces damages people or develops them and where most participants see veterans are suffering more than average from mental, physical, or emotional issues (Yougov, 2018). However, this study also found that the words that are chosen to describe veterans are predominately positive in nature with "brave" the most commonly mentioned, especially among younger age groups.

2. Are beliefs about veterans contextually and situationally dependent or are they globally consistent? How do perceptions of veterans compare with perceptions of soldiers?

The results suggest that the coexistence of contradictory, positive heroizing, and negative victimizing core beliefs about veterans may be explained by cognitive 
polyphasia (Moscovici, 2000). Specifically, "heroizing associations" and "victimizing associations" were found to be embedded within different contexts in both the "veteran" and the "soldier." While victimizing sentiments were related to superficial descriptions of the individual in the context of the unique challenges of deployment, heroizing associations related to anticipations of inherent qualities and character dispositions. Veterans may be understood as heroes and victims as contextually coherent rationalities may justify both beliefs. Therefore, situational cues and contextual information may impact whether veterans are characterized as heroes or victims.

In summary, the present findings were aligned with previous research. For example, the relationship between the stimuli words "veteran"/"soldier" and heroizing associations may resonate with the historical and cultural dimension of knowledge. Specifically, heroic sentiments that individuals recalled when characterizing veterans and soldiers may be explained by cultural conceptualizations of military service (i.e., Coy et al., 2008; Gibson, 2012; Gibson \& Condor, 2009). The deeply rooted cultural assumption in the UK that military service represents a sacred duty (Gibson, 2012) may therefore imply that those who carry out this sacred duty are similarly sacred people.

In contrast to heroizing associations, the results suggest that the victimization of military-related representations may be a less deeply rooted cultural assumption as being only in central core of the "veteran" representation. The findings align with previous research that victimizing sentiments may be related to conceptualizations of war as a reason for suffering (McCartney, 2011; McGarry, 2012). Therefore, the results suggest that the more the experience of war is subject to public scrutiny and debate, the more those who have made this experience may be labeled as victim (cf. Chattarji, 2000; De Groot, 1995; Goldensohn, 2006; Jones \& Wessely, 2005).

Since victimhood was generally more associated with being a veteran, this may imply that leaving the armed forces is associated with negative outcomes, and this certainly seems to be the case in other studies of public perceptions of veterans (Yougov, 2018). This polling also seemed to suggest that many believe that people only leave the armed forces because they have been damaged in service, and so all veterans by default are damaged. This would help explain why veterans seem to be more centrally associated with victimhood.

However, the results also suggest experience and older age were strongly related to victimizing associations. Therefore, the evocation of victimizing sentiments may be related to the etymological origin of the word "veteran," referring to old age (Stevenson, 2010). Research indicates that the image of old people is stained by negative stereotypes, relating to ill-health and economic inactivity (Tuckman \& Lorge, 1953). For example, intellectual and physical decline are central elements in characterizing "old people" (cf. Gaymard, 2006). Therefore, stereotypes that relate to old age may play a pivotal role in the victimization of veterans. In this sense, the present findings were not fully aligned with previous research that indicated veterans were conceptualized as victims solely from their perceived war 
exposure (cf. McGarry, 2012; McGarry \& Ferguson, 2012; Walklate, 2007). Given the link with old age, it could be that participants also associate "veteran" with conflicts such as World War 2 and the Korean War where soldiers were predominately conscripts and where there was considerable societal pressure to serve in the armed forces. This may contrast with views about younger veterans who volunteer for service in the armed forces. Data from polling in the UK suggests that the word veteran is associated with older age and conflicts from the mid-20th century (YouGov, 2018).

In conclusion, the absence of "positive characterizations of the personality" in the "veteran" representation's core may be explained by a relationship between victimizing and stigmatizing sentiments. As an overt discrimination of those who have served in the armed forces is deemed to be socially unacceptable, research indicates that veterans with service-related injuries are subject to implicit stigmatization (Kleykamp et al., 2018; MacLean \& Kleykamp, 2014). Therefore, if individuals recalled victimizing sentiments when characterizing soldiers and veterans, then they may have been less likely to use positive characterizations to describe inherent traits.

Although the results provided a formulative, exploratory analysis of the structures of beliefs about veterans and soldiers, a number of caveats need to be taken into consideration. As the sample comprised a high proportion of White, well-educated females in their mid-20s, the present findings may not be considered as representative of the British general public. Older people and men tend to be more supportive of their military and its (ex)members (cf. Clements, 2011; Hines et al., 2015; Scotto et al., 2011; cf. also Manigart, 1996). Females have less knowledge of the armed forces in the UK than males and are less likely to express interest in joining the armed forces (YouGov, 2018). Females are also more likely to associate poor mental health conditions with veterans (Yougov, 2018). It could be argued that females have generally a lower interest in the UK Armed Forces, making the UK Armed Forces a less significant institution for them. Consistently low recruitment and employment rates for women in the UK Armed Forces could be explained by perceptions of the Armed Forces as epitomizing a bastion of traditional masculinist values (Woodward \& Duncanson, 2016). This may be particularly problematic in the context of the HEM models, being descriptive in nature. Therefore, it would be advisable for future studies to recruit a more representative population.

The use of the term "veteran" to describe those who have left the UK Armed Forces may have been a limitation of the study. Recent polling suggests that while widely recognized, the label "veteran" may not be widely used in conversation in the UK and is associated with older age (YouGov, 2018). This chimes with interviews with veterans in the UK who themselves often reject the label "veteran" and prefer labels such as "ex-service personnel" instead (Burdett et al., 2013). The close association of veteran in this study with age may then actually represent a subgroup of older people who have served in the armed forces, and this may be at the heart of the more negative associations allied with "veteran." A study that also examines terms such as "ex-service leaver" or "ex-service leaver" would be useful to make the 
contrast with veteran. "Soldier," while it is also a widely recognized label, does tend to conjure up someone from the army and not members of the other Armed Services such as the Royal Navy, Royal Marines, or Royal Air Force. "Soldier" may also be more associated with the combat roles in the army rather than the broad expanse of other logistic and support roles also available to members of the army.

Another caveat that needs to be taken into consideration was the low variance scores of the PCA which did not reach the generally accepted threshold of $40 \%$. An increased number of components such as three-, four-, five- or six-factor models instead of the two-factor model chosen would have increased the explained variance. However, each component would not have accommodated three item loadings above the cutoff point of .4 (Costello \& Osborne, 2005; Raubenheimer, 2004) and thus would have violated a commonly accepted threshold.

However, the present study investigating the social representational structure of veterans and soldiers has provided some first insights in this area. The data suggest that serving soldiers may be more favorably viewed than veterans. When thinking of veterans, the public may be more inclined to reflect on their perceived older age and their victimization through the experience of war. The publicly pertinent victimization of veterans may be related to public conceptualizations of war (i.e., Gibson, 2012; McCartney, 2011) and the etymology of the word veteran, meaning old age (cf. Tuckman \& Lorge, 1953).

\section{Declaration of Conflicting Interests}

The authors declared no potential conflicts of interest with respect to the research, authorship, and/or publication of this article.

\section{Funding}

The author(s) disclosed receipt of the following financial support for the research, authorship, and/or publication of this article: This article was based on work submitted for a doctoral thesis funded by Oxford Brookes University.

\section{ORCID iD}

Rita Helena Phillips (D) https://orcid.org/0000-0002-4541-2565

Vincent Connelly (D) https://orcid.org/0000-0001-7142-7464

\section{References}

Abric, J. C. (1987). Coopération, compétition et représentations sociales [Cooperation, competition and social representations]. Delval.

Abric, J. C. (1989). L'etude experimentale des representations sociales [The experimental study of social representations]. In D. Jodelet (Ed.), Les representations sociales [Social representations]. PUF.

Abric, J. C. (1996). Specific processes of social representations. Papers on Social Representations, 5, 77-80. 
Abric, J. C. (2003). La recherche du noyau central et de la zone muette des représentations sociales. In J. C. Abric (Ed.), Méthodes d'étude des représentations sociales (pp. 59-80). Ramonville Saint-Agne.

Armour, C., Waterhouse-Bradley, B., Ross, J., McLafferty, M., \& Hall, M. (2018). Public attitudes to the UK armed forces in Northern Ireland. Ulster University and Forces in Mind Trust.

Ashcroft, M. (2014). The veterans' transition review. Biteback.

Ashcroft, M., \& KCMG. (2012). The Armed Forces and Society: The military in Britainthrough the eyes of Service personnel, employers and the public. http://lordashcroftpolls. com/wp-content/uploads/2012/05/THE-ARMED-FORCES-SOCIETY.pdf

Ashcroft, M.KCMG. (2017). The veterans' transition review (Revised) Biteback

Baquiano, M. J., \& Mendez, A. J. P. (2016). Social representations of climate change: a crosscultural investigation. American International Journal of Contemporary Research, 6(1), $1-9$.

Bardin, L. (1977). L'Analyse de contenu [Content analysis]. Presses Universitaires de France.

Beavers, A. S., Lounsbury, J. W., Richards, J. K., Huck, A. W., Skolits, G. J., \& Esquivel, S. L. (2013). Practical considerations for using exploratory factor analysis in educational research. Practical Assessment, Research, and Evaluation, 18(6). https://doi.org/10.7275/ qv2q-rk76

Ben-Zeev, D., Corrigan, P. W., Britt, T. W., \& Langford, L. (2012). Stigma of mental illness and service use in the military. Journal of Mental Health, 21(3), 264-273.

Bolasco, S., Morrone, A., \& Baiocchi, F. (1999). A paradigmatic path for statistical content analysis using an integrated package of textual data treatment. In Classification and data analysis (pp. 237-246). Springer.

British Army Social Research, BMG Research. (2017, February). Research report. http:// wwwbmgresearch.co.uk/armyresearch/

British Social Attitudes. (2012). http://www.bsa.natcen.ac.uk/media/38852/bsa29_full_ report.pdf

Burdett, H., Woodhead, C., Iversen, A. C., Wessely, S., Dandeker, C., \& Fear, N. T. (2013). “Are you a veteran?" Understanding of the term 'veteran' among UK ex-service personnel: A research note. Armed Forces \& Society, 39(4), 751-759.

Chattarji, S. (2000). Representations of Vietnam in some poems of John Balaban, Kevin Bowen, and Bruce Weigl. WLA, 12(1), http://wwwwlajournal.com/12_1/current.html

Clemence, A., Doise, W., \& Lorenzi-Cioldi, F. (2014). The quantitative analysis of social representations. Routledge.

Clements, B. (2011). 'Hawks' and 'Doves' public opinion in Britain towards overseas military interventions. Political Insight, 2(3), 12-15.

Connelly, V., \& Burgess, M. (2013). Re: Suicide among Falkland war veterans. BMJ, 346, f3204.

Conway, J. M., \& Huffcutt, A. I. (2003). A review and evaluation of exploratory factor analysis practices in organizational research. Organizational Research Methods, 6(2), $147-168$. 
Costello, A. B., \& Osborne, J. W. (2005). Best practices in exploratory factor analysis: Four recommendations for getting the most from your analysis. Practical Assessment, Research \& Evaluation, 10(7), 1-9.

Coy, P. G., Woehrle, L. M., \& Maney, G. M. (2008). Discursive legacies: The U.S. peace movement and "support the troops." Social Problems, 55(2), 161-189.

Dany, L., Urdapilleta, I., \& Monaco, G. L. (2015). Free associations and social representations: Some reflections on rank-frequency and importance-frequency methods. Quality \& Quantity, 49(2), 489-507.

De Groot, G. J. (1995). The limits of moral protest and participatory democracy: The Vietnam Day Committee. The Pacific Historical Review, 64(1), 95-119.

di Giacomo, J. P. (1980). Intergroup alliances and rejections within a protest movement (analysis of the social representations). European Journal of Social Psychology, 10(4), 329-344.

Festinger, L. (1957). Cognitive dissonance theory. 1989 Primary Prevention of HIV/AIDS: Psychological approaches. Sage.

Flament, C. (1994). Structure, dynamique et transformation des représentations sociales. In J. C. Abric (Ed.), Pratiques sociales, representations (pp. 37-57). Puf.

Forster, A. (2006). Breaking the covenant: Governance of the British army in the twenty-first century. International Affairs, 82(6), 1043-1057.

Gaymard, S. (2006). The representation of old people: Comparison between the professionals and students. Revue internationale de psychologie sociale, 19(3), 69-91.

Gibson, S. (2012). Supporting the troops, serving the country: Rhetorical commonplaces in the representation of military service. In S. Gibson \& S. Mollan (Eds.), Representations of peace and conflict (pp. 143-159). Palgrave Macmillan.

Gibson, S., \& Condor, S. (2009). State institutions and social identity: National representation in soldiers' and civilians' interview talk concerning military service. British Journal of Social Psychology, 48(2), 313-336.

Goldensohn, L. (2006). Dismantling glory. Columbia University Press.

Gomes, A. M. T., Oliveira, D. C. D., \& Sá, C. P. D. (2008). Social representations of the Brazilian national health care system in the city of Rio de Janeiro, Brazil, according to the structural approach. Revista Latino-Americana de Enfermagem, 16(1), 122-129.

Greene-Shortridge, T. M., Britt, T. W., \& Castro, C. A. (2007). The stigma of mental health problems in the military. Military Medicine, 172(2), 157-161.

Hines, L. A., Gribble, R., Wessely, S., Dandeker, C., \& Fear, N. T. (2015). Are the armed forces understood and supported by the public? A view from the United Kingdom. Armed Forces \& Society, 41(4), 688-713.

Hipes, C., Lucas, J. W., \& Kleykamp, M. (2015). Status-and stigma-related consequences of military service and PTSD: Evidence from a laboratory experiment. Armed Forces \& Society, 41(3), 477-495.

Hoerster, K. D., Lehavot, K., Simpson, T., McFall, M., Reiber, G., \& Nelson, K. M. (2012). Health and health behavior differences: U.S. Military, veteran, and civilian men. American Journal of Preventive Medicine, 43(5), 483-489. 
Ipsos MORI. (Autumn, 2013). Armed Forces Reputation survey. Ministry of Defence. https:// www.gov.uk/government/uploads/system/uploads/attachment_data/file/326825/2014063 0-mod-reputation-survey-autumn-2013.pdf

Ipsos MORI. (March, 2012). Armed Forces Reputation survey. Ministry of Defence. https:// www.gov.uk/government/uploads/system/uploads/attachment_data/file/27216/2012_ march_mod_pos.pdf

Ipsos MORI. (March, 2013). Armed Forces Reputation survey. Ministry of Defence. https:// www.gov.uk/government/uploads/system/uploads/attachment_data/file/230255/MOD_ external_opinion_survey_Spring_2013_top_lines.pdf

Ipsos MORI. (September, 2012). Armed Forces Reputation survey. Ministry of Defence. https://www.gov.uk/government/uploads/system/uploads/attachment_data/file/230254/ MOD_external_opinion_survey_Autumn_2012_top_lines.pdf

Ipsos MORI. (Spring, 2014). Armed Forces Reputation survey. Ministry of Defence. https:// www.gov.uk/government/uploads/system/uploads/attachment_data/file/326827/2014063 0-mod-reputation-survey-spring-2014.pdf

Ipsos MORI. (Summer, 2015). Armed Forces Reputation survey. Ministry of Defence. https:// www.gov.uk/government/uploads/system/uploads/attachment_data/file/470940/ 20151026-MOD_and_AF_Reputational_Polling_June2015_Topline_Gov.uk.pdf

Ipsos MORI. (Winter, 2014). Armed Forces Reputation survey. Ministry of Defence. https:// www.gov.uk/government/uploads/system/uploads/attachment_data/file/470938/ 20151026-MOD_and_AF_Reputational_Polling_December2014_Topline_Gov_uk_ updated.pdf

Jodelet, D. (1991). Madness and social representations. Harvester Wheatsheaf.

Joffe, H., \& Staerklé, C. (2007). The centrality of the self-control ethos in Western aspersions regarding outgroups: A social representational approach to stereotype content. Culture \& Psychology, 13(4), 395-418.

Jones, E., \& Wessely, S. (2005). Shell shock to PTSD: Military psychiatry from 1900 to the Gulf War. Psychology Press.

Jovchelovitch, S. (2001). Social representations, public life and social construction. In K. Deaux \& G. Philogene (Eds.), Representations of the social: Bridging theoretical traditions (pp. 257-270). Blackwell.

King's Centre for Military Health Research. (2014). A 15 year report on PTSD in the armed forces. https://www.kcl.ac.uk/kcmhr/publications/

Kleykamp, M., Hipes, C., \& MacLean, A. (2018). Who supports US veterans and who exaggerates their support? Armed Forces \& Society, 44(1), 92-115.

Link, B. G., Phelan, J. C., Bresnahan, M., Stueve, A., \& Pescosolido, B. A. (1999). Public conceptions of mental illness: Labels, causes, dangerousness, and social distance. American Journal of Public Health, 89(9), 1328-1333.

Lo Monaco, G., Delouvée, S., \& Rateau, P. (2016). Les représentations sociales. Théories, méthodes et applications [Social representations. Theories, methods and applications]. De Boeck.

Lo Monaco, G., Piermatteo, A., Rateau, P., \& Tavani, J. L. (2017). Methods for studying the structure of social representations: A critical review and agenda for future research. Journal for the Theory of Social Behaviour, 47(3), 306-331. 
Lorenzi-Cioldi, F. (1988). Individus dominants et groupes dominés: Images masculines et féminines. Presses universitaires de Grenoble.

MacLean, A., \& Kleykamp, M. (2014). Coming home: Attitudes toward US veterans returning from Iraq. Social Problems, 61(1), 131-154.

Manigart, P. (Ed.). (1996). Future roles, missions and structures of Armed Forces in the new world order: The public view. Nova Science Publishers.

McCartney, H. (2011). Hero, victimor villain? The public image of the British soldier and its implications for defense policy. Defense \& Security Analysis, 27(1), 43-54.

McCulloch, J. (1995). Colonial psychiatry and the African mind. Cambridge University Press.

McGarry, R. (2012). Developing a victimological imagination: An auto/biographical study of British military veterans [Doctoral dissertation]. Liverpool Hope University.

McGarry, R., \& Ferguson, N. (2012). Exploring representations of the soldier as victim: From Northern Ireland to Iraq. In S. Gibson \& S. Mollan (Eds.), Representations of peace and conflict (pp. 120-142). Palgrave Macmillan.

MOD. (2014). Career Transition Partnership ex-service personnel employment outcomes statistics: Background quality report. URL:https://www.gov.uk/government/statistics/ career-transition-partnership-ex-service-personnel-employment-outcomes-statistics-back ground-quality-report

MOD Statistic Notice. (2015). https://www.gov.uk/government/uploads/system/uploads/ attachment_data/file/416463/20150326_UK_AF_Suicide_National_Statistic_2015_ Data_O.pdf

Moscovici, S. (1984). The phenomenon of social representations. In R. Farr \& S. Moscovici (Eds.), Social representations (pp. 3-69). Cambridge University Press.

Moscovici, S. (1988). Notes towards a description of social representations. European Journal of Social Psychology, 18(3), 211-250.

Moscovici, S. (2000). Social representations: Explorations in social psychology. Polity Press. Moscovici, S. (2001). Social representations: Essays in social psychology. NYU Press.

Phillips, R., Connelly, V., \& Burgess, M. (in press). Representations of UK armed forces Veterans in the press: A quantitative analysis of newspaper articles. Journal of Political and Military Sociology, 47.

Provencher, C. (2011). Towards a better understanding of cognitive polyphasia. Journal for the Theory of Social Behaviour, 41(4), 377-395.

Raubenheimer, J. (2004). An item selection procedure to maximize scale reliability and validity. SA Journal of Industrial Psychology, 30(4), 59-64.

Roland-Lévy, C., Boumelki, F. E. P., \& Guillet, E. (2010). Representation of the financial crisis: Effect on social representations of savings and credit. The Journal of Socio-Economics, 39(2), 142-149.

Sarrica, M., \& Wachelke, J. (2010). Peace and war as social representations: A structural exploration with Italian adolescents. Universitas Psychologica, 9(2), 315-330.

Scotto, T. J., Reifler, J., Clarke, H. D., Diaz Lopez, J. A., Sanders, D., Stewart, M. C., \& Whiteley, P. (2011). Briefing paper: Attitudes towards British involvement in Afghanistan. 
Institute for Democracy \& Conflict Resolution. IDCR-BP-03/11. Retrieved November 4, 2016, from http://www.idcr.org.uk/wpcontent/uploads/2010/09/03_11.pdf

Secretary of State for Defense. (2018). The strategy for our veterans. https://assets.publishing. service.gov.uk/government/uploads/system/uploads/attachment_data/file/755915/Strat egy_for_our_Veterans_FINAL_08.11.18_WEB.pdf

Sellars, W., Rorty, R., Rorty, R. M., \& Brandom, R. (1997). Empiricism and the philosophy of mind (Vol. 1). Harvard University Press.

SSAFA. (2019). The Nation's Duty: Challenging society's disservice to a new generation of veterans. https://www.ssafa.org.uk/media/22rnldxl/the-nations-duty-ssafa-researchreport.pdf

Stevenson, A. (Ed.). (2010). Oxford dictionary of English. Oxford University Press.

Thompson, J., Van Til, L., Poirier, A., Sweet, J., McKinnon, K., Sudom, K., Dursun, S., \& Pedlar, D. (2014). Health and well-being of Canadian armed forces veterans: Findings from the 2013 life after service survey. Charlottetown Research Directorate, Veterans Affairs Canada. http:// wwwveterans.gc.ca/pdf/aboutus/research-directorate/2013-survey-caf-health.pdf

Tuckman, J., \& Lorge, I. (1953). Attitudes toward old people. Journal of Social Psychology, 37, 249-260.

Wagner, W., Duveen, G., Verna, J., \& Themel, T. (2000). I have some faith and at the same time I dont believe in it. Cognitive polyphasia and cultural change. Journal of Community and Applied Social Psychology, 10(4), 301-314.

Walklate, S. (2007). Handbook of victims and victimology. Routledge.

Woodward, R., \& Duncanson, C. (2016). Gendered divisions of military labour in the British Armed Forces. Defence Studies, 16(3), 205-228.

YouGov. (2018). Public perceptions of veterans and the armed forces. https://www.fim-trust. org/wp-content/uploads/2018/11/20181002-YouGov-perceptions-final.pdf

\section{Author Biographies}

Rita Phillips completed her $\mathrm{PhD}$ at Oxford Brookes University. As a lecturer in Psychology she focusses her research around social psychological phenomena in everyday life, working mainly in the US and the UK context. In her recent research, Rita focussed on a phenomenological understanding of individual experiences with religion and the consequences that belief may have on life-choices and self-perceived happiness. Rita's work was distinguished with international awards such as the "Emerging Scholar Award" at the conference "Religion in Society 2018" at the University of Berkeley, CA.

Vince Connelly is a professor of psychology at Oxford Brookes University in the UK. He has been involved in a number of research projects regarding military personnel, families and veterans over the last ten years. A number of these focus on reservists and their relationships within the military and how they juggle their lives between their families and their civilian and military employers. Other projects have included working with the British Army to provide practical advice to those 
leaving the Army as well reviews of military mental health provision and military engagement with society. Vince also has an interest in special education and has published widely on the development of writing skills across the lifespan.

Mark Burgess received his $\mathrm{PhD}$ from the University of Alberta and is a Reader in Psychology at Oxford Brookes University. His research focuses on Transformative Experiences. As part of this research he has interviewed terrorists, peaceful protestors, victims of violence, politicians, and military personnel. He also interviews professional artists, musicians and sportsmen and women about their lives. Current work is focused largely on people's experiences of erotic love over their lifespan. 